\title{
ACCOUNTING FOR LEVEE OVERTOPPING DURATION: A TEST WITH HURRICANE KATRINA CONDITIONS
}

\author{
Robert G. Dean ${ }^{1}$ and Mathijs van Ledden ${ }^{2}$
}

\begin{abstract}
Overtopping of earthen levees can result in lee side erosion, levee failure and severe flooding consequences. Erosion takes time and early design guidance did not account for overtopping duration. The potential overtopping durations associated with hurricanes depends on the time histories of the surges and waves and are usually shorter than for riverine or coastal flooding by other storm types. With significant advancements in hurricane-induced storm surge modeling, it is appropriate to improve predictability of levee erosion response characteristics. This paper presents the results of a blind-folded comparison of a method developed by Dean, et al (2010) to two levee locations in the New Orleans area. The levees failed in one area where the surges and wave heights were larger than the second area where the levees performed well. The method applied accounts for surge and wave time histories, levee geometry and grass cover quality. Results are consistent with failure at the location of higher surges and wave heights and consistent with the non-failure at the second location for good quality grass. For average and poor quality grass covers, the required levee heights are $0.1 \mathrm{~m}$ and 0,5 $\mathrm{m}$ higher that the actual levee height. The method can be applied to optimize levee design, for example, through investigating the trade offs between crest elevation and levee side slopes.
\end{abstract}

Keywords: levee overtopping, levee erosion, hurricanes, duration

\section{INTRODUCTION}

Considerable efforts have been directed to understanding the mechanics of levee overtopping by waves, erosion limits to retain levee functionality and development of appropriate design criteria. The results of these efforts are summarized as recommended design criteria in van der Meer (2002, hereafter referred to as the "TAW Manual”), the EuroTop Manual (2007) and the U. S. Army Corps of Engineers Coastal Engineering Manual (2008). Recent advances in understanding hurricanes and their parameters through sophisticated storm surge and wave prediction models have improved capabilities to predict the time variation of the "forcing" agents causing wave overtopping characteristics. However, the "response" characteristics of levee erosion are not described by fundamental laws as are the hydrodynamics and thus capabilities to predict levee failure have lagged. Design is complicated by along levee variability in levee characteristics resulting in the unavoidable increase in probability of levee failure with increasing levee length.

Until recently, design criteria for grass covered levees were based solely on the magnitude of levee overtopping and grass cover quality and did not include duration although it is well known that time is required to accomplish sufficient erosion to compromise levee functionality. Experiments by Whitehead, et al. (1976) and Hewlett, et al. (1987) established design criteria for levee failures due to steady flow and quantified the roles of duration, threshold conditions for damage and levee surface quality. Recent full scale experiments by van der Meer and colleagues (Van der Meer, et al., 2006; Hoffmans, et al., 2008; Van der Meer, 2008; and Akkermann, et al. ,2007) in which a Wave Overtopping Simulator is placed on the crest of an actual levee have also underscored the design significance of these three factors. Additional recent contributions include the detailed characteristics of levee grass covers that contribute to levee erosion resistance, eg. Young (2005). Schuttrumpf (2003), among others has discussed the need to account for overtopping duration in design.

This paper presents the results of a blind-folded application of recently developed methodology to Hurricane Katrina at two locations on the St. Bernard (New Orleans area) levee system. The method accounts for time varying storm surge and wave conditions and levee characteristics. At one location where the levees failed, the storm surges and wave heights were significantly larger than at the second location where the levee performed well.

\footnotetext{
${ }^{1}$ Civil and Coastal Engineering, Univ. of Florida, Gainesville, FL 32611 U. S. A.

${ }^{2}$ Royal Haskoning, c/o New Orleans District, U. S. Army Corps of Engineers, New Orleans, LA
} 


\section{DESCRIPTION OF METHODOLOGY}

Dean, et al (2010) developed an approach to levee design for wave overtopping that includes rational consideration of wave overtopping duration and magnitude and levee cover characteristics. The approach is based on analysis of the Hewlett, et al. (1987) results for steady flow overtopping as shown in Figure 1 and is described briefly below.

Referring to Figure 1, the Hewlett results are for steady flow and establish thresholds of acceptable overtopping for different combinations of overtopping magnitude and duration for three qualities of grass cover: "poor”, “average” and "good”. Transferring the steady flow results of Hewlett to represent intermittent wave overtopping required the steps illustrated in the Flow Chart in Figure 2. Each of these steps is described briefly below.

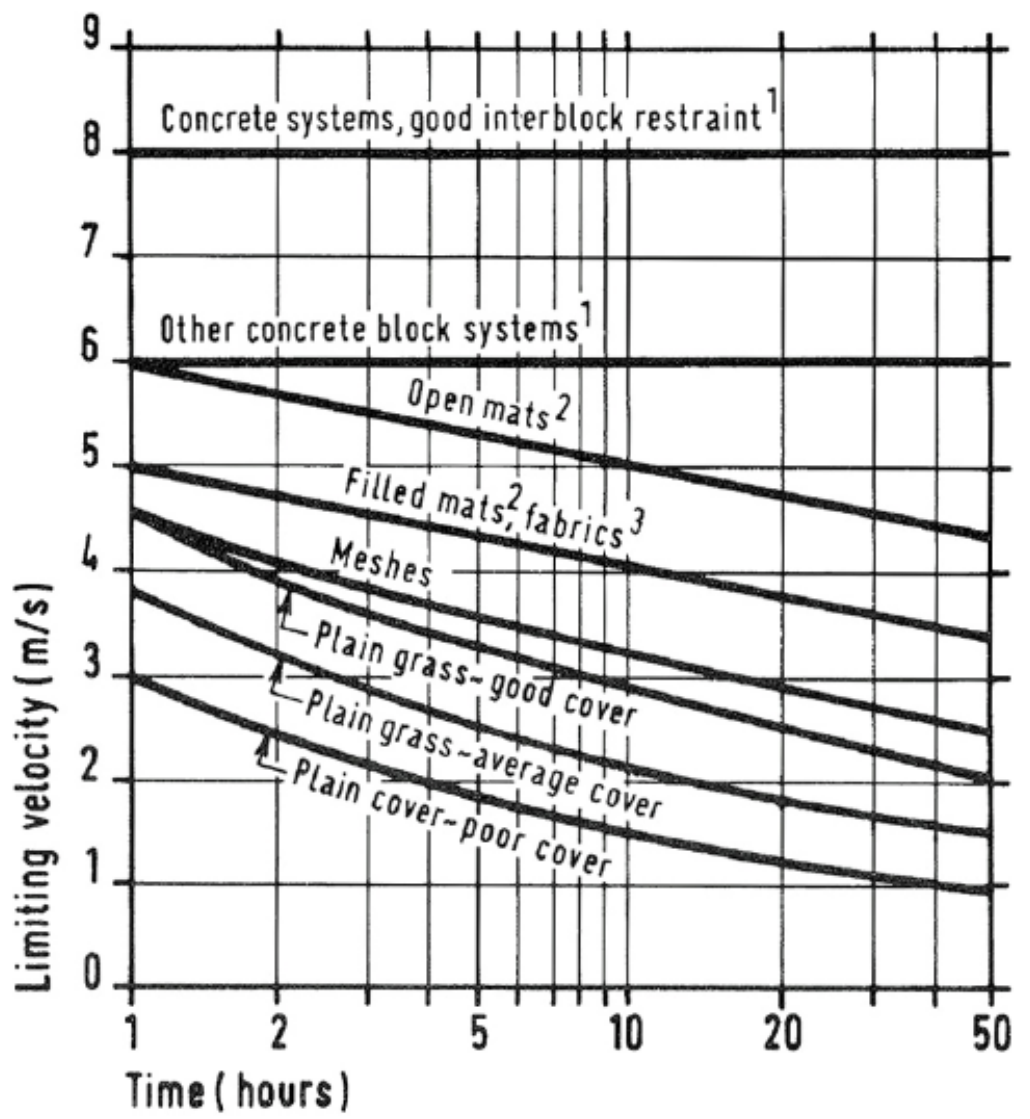

Figure 1. Combinations of velocities and durations for acceptable erosion of various coverings due to steady overtopping (Hewlett, et al. 1987).

\section{Flow Characteristics at Inner Levee Toe}

Based on typical ranges of levee slopes and roughnesses and consideration that critical flow occurs at the inboard (landward) side of the levee crest, it was established that uniform supercritical flow occurs at the landward toe of the levee. This greatly simplifies later consideration of the velocities associated with levee degradation. This uniform flow velocity was found to be proportional to the cube root of the discharge which was later determined to be serendipitous as seen in the section on "Erosion Index" below. 


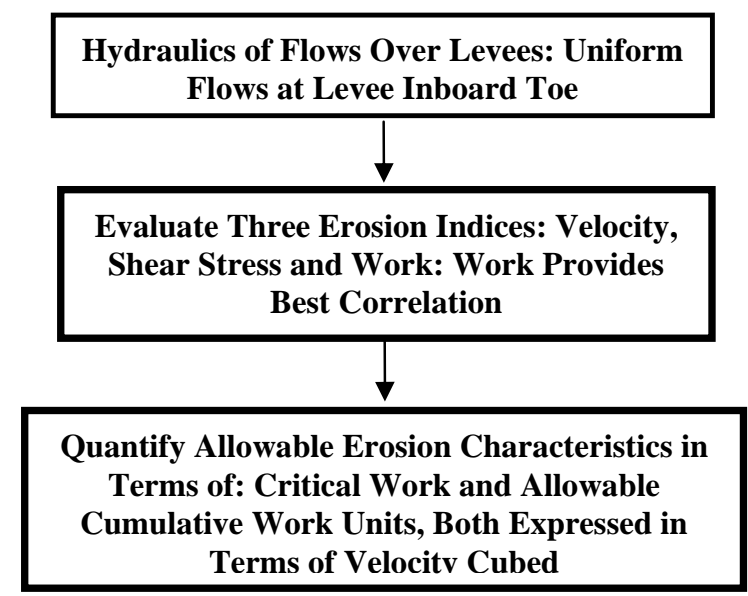

Figure 2. Flow Chart of Methodology Development From Hewlett, et al. Results.

\section{Erosion Index}

Three erosion indices were developed and evaluated with the Hewlett data: (1) Velocity above a threshold and an acceptable level of cumulative velocity above the threshold, (2) Shear stress above a threshold and an acceptable level of cumulative shear stress above the threshold, and (3) Power (herein called "work") above a threshold and an acceptable level of cumulative work above the threshold. Comparison of these three indices established that the work index provided a substantially better fit to the Hewlett data than did the two other indices. Because work is proportional to velocity cubed which, as noted previously, is proportional to overtopping per unit width, the task of applying this index is simplified significantly. Table 1 summarizes the thresholds (expressed in $\mathrm{m} / \mathrm{s}$ ) and allowable cumulative work units ${ }^{3}$ (expressed in $\mathrm{m}^{3} / \mathrm{s}^{2}$ ) for the three grass cover qualities.

\begin{tabular}{|c|c|c|c|}
\hline \multirow[t]{2}{*}{ Parameter for Energy Basis } & \multicolumn{3}{|c|}{ Grass Cover Quality } \\
\hline & Good & Average & Poor \\
\hline Threshold Velocity, $u_{c}(\mathrm{~m} / \mathrm{s})$ & 1.8 & 1.3 & 0.76 \\
\hline Cumulative Work Units $\left(\mathrm{m}^{3} / \mathrm{s}^{2}\right)$ & $0.492 \times 10^{6}$ & $0.229 \times 10^{6}$ & $0.103 \times 10^{6}$ \\
\hline
\end{tabular}

The application of the results in Table 1 is illustrated for good quality grass cover as

$$
\sum_{n=1}^{N}\left(u_{n}^{3}-u_{c}^{3}\right) \Delta t_{n} \leq 0.492 \times 10^{6} \mathrm{~m}^{3} / \mathrm{s}^{2}, \text { providing } u_{n}>u_{c}
$$

\section{Wave Overtopping}

Wave overtopping volume was considered to be proportional to the excess runup defined as the runup exceeding the levee crest. Runup was assumed to be Rayleigh distributed and represented as the potential runup height if the levee slope were extended without limit. The effects of the waves that were not sufficiently high to overtop the levee and the limited portion of the wave period during which the waves overtopped the levee were taken into consideration in calculating the overtopping discharge magnitude. Both of these effects increase the magnitude of the overtopping while it occurs. Finally, the average of the overtopping was "calibrated" to ensure consistency with the TAW methodology.

\footnotetext{
${ }^{3}$ Note: The terminology “cumulative erosional work units” is also used herein.
} 


\section{METHOD APPLICATION}

For given levee characteristics (height, slope and grass quality) and hydrodynamic conditions (time variations of surges and wave characteristics), the amount of cumulative "work" conducted by the overtopping events on the levee leeside was calculated as a function of time as follows. The time of overtopping was divided into periods over which it was considered that the surge and wave conditions were reasonably constant. The work done by the overtopping events was calculated for each period and added to that for preceding periods. This cumulative work was compared with the threshold for unacceptable damage to determine whether the levee could withstand the conditions up to that time. The Dean et al paper documented, through examples, the effects of grass cover quality, ranges of levee heights and storm surge duration. Figure 3 presents a flow chart of the method application. The Reader is referred to Dean, et al (2010) for additional detail on the method.

\section{HURRICANE KATRINA}

Hurricane Katrina made landfall in southern Louisiana on August 29, 2005, see Figure 4. Although Category 3 at landfall, Katrina had been a Category 5 hurricane approximately 15 hours prior to landfall and was unusually large for a storm of that magnitude with a radius to maximum winds at landfall of $54 \mathrm{~km}$. Of special significance were the unprecedented storm surges caused by Hurricane Katrina. The maximum storm surge quantified by High Water Marks (HWMs) occurred in Mississippi to the east of New Orleans and was some $8.2 \mathrm{~m}$ above North American Vertical Datum (approximately Mean Sea Level). This storm surge along the Gulf of Mexico coastline is believed to be due to, in part, the large size of the storm and its Category 5 magnitude prior to landfall. Although the winds decreased as the storm approached shore, the earlier wind speeds and large hurricane size had generated a surge that continued shoreward, shoaling as it propagated.

Hurricane Katrina surges exceeded design conditions along the levees in the New Orleans area. The return period of the surges associated with Hurricane Katrina have been estimated at approximately 400 years compared to design conditions of 100 years (IPET, Volume VII, 2008b). Moreover at some locations, the levee elevations were less than their design level due to subsidence, consolidation and other factors. These surges and waves caused levee failures at a number of locations, one of which is shown in Figure 5 which identifies the two levee locations examined in this paper. At Location 1, the levee failed; however, at Location 2, the levee performed well throughout the storm.

For applications herein, storm surges and wave characteristics were calculated with the ADCIRC and STWAVE models, respectively.

\section{Location 1: Case of Levee Failure}

Figure 6 is a photograph of levee failure in the general vicinity of Location 1 which is located at the Corps of Engineers Station 430. The calculated storm surge and wave conditions are available in the Corps of Engineers’ IPET forensic Study (2008b) at https://ipet.wes.army.mil/.

Levee failure near this location was also investigated by Storesund, et al (2010) who concluded that the levee failed through erosion from the flood side; however, there are several features of their analysis with which we do not concur.

The calculated variations of storm surge and significant wave heights for Location 1 are presented in Figure 7. The IPET calculated wave heights represent conditions some $70 \mathrm{~m}$ from the toe of the levee and considerable vegetation exists between the levee toe and the location where the IPET calculations apply. Wave damping by vegetation has been investigated by Dean (1978), Kobayashi, et al. (1993), Lima, et al. (2006), among many others. One approach to representing wave damping is to consider a geometry in which the vegetation is considered as surface piercing vertical cylinders of diameter, $D$, arranged on a square array at a spacing, $S$. The resulting rate of energy dissipation, $\varepsilon$, is given by the time averaged product of the drag force, $F_{D}$ and the wave induced particle velocity, $u$, ie 


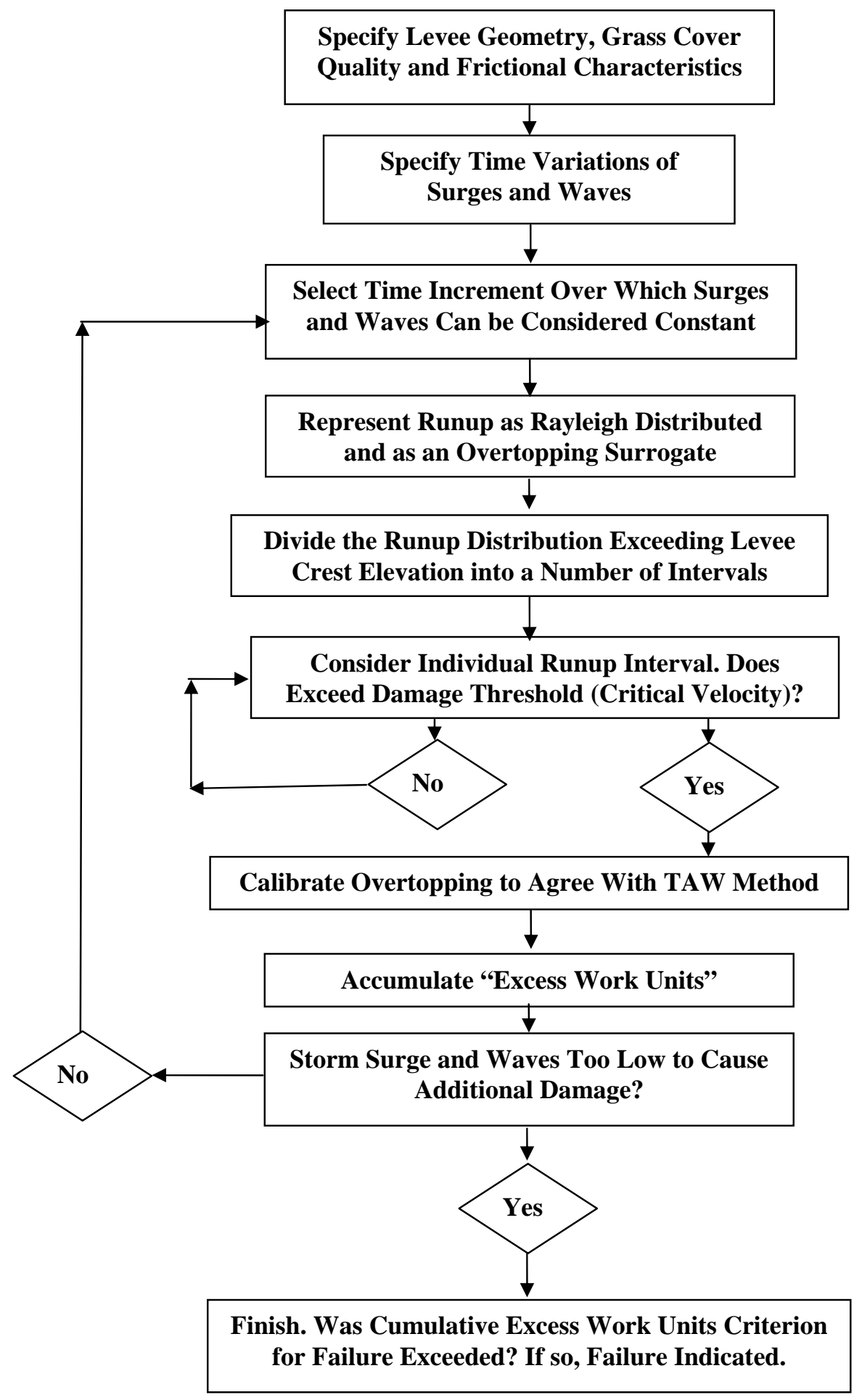

Figure 3. Flow Chart of Methodology Application. 


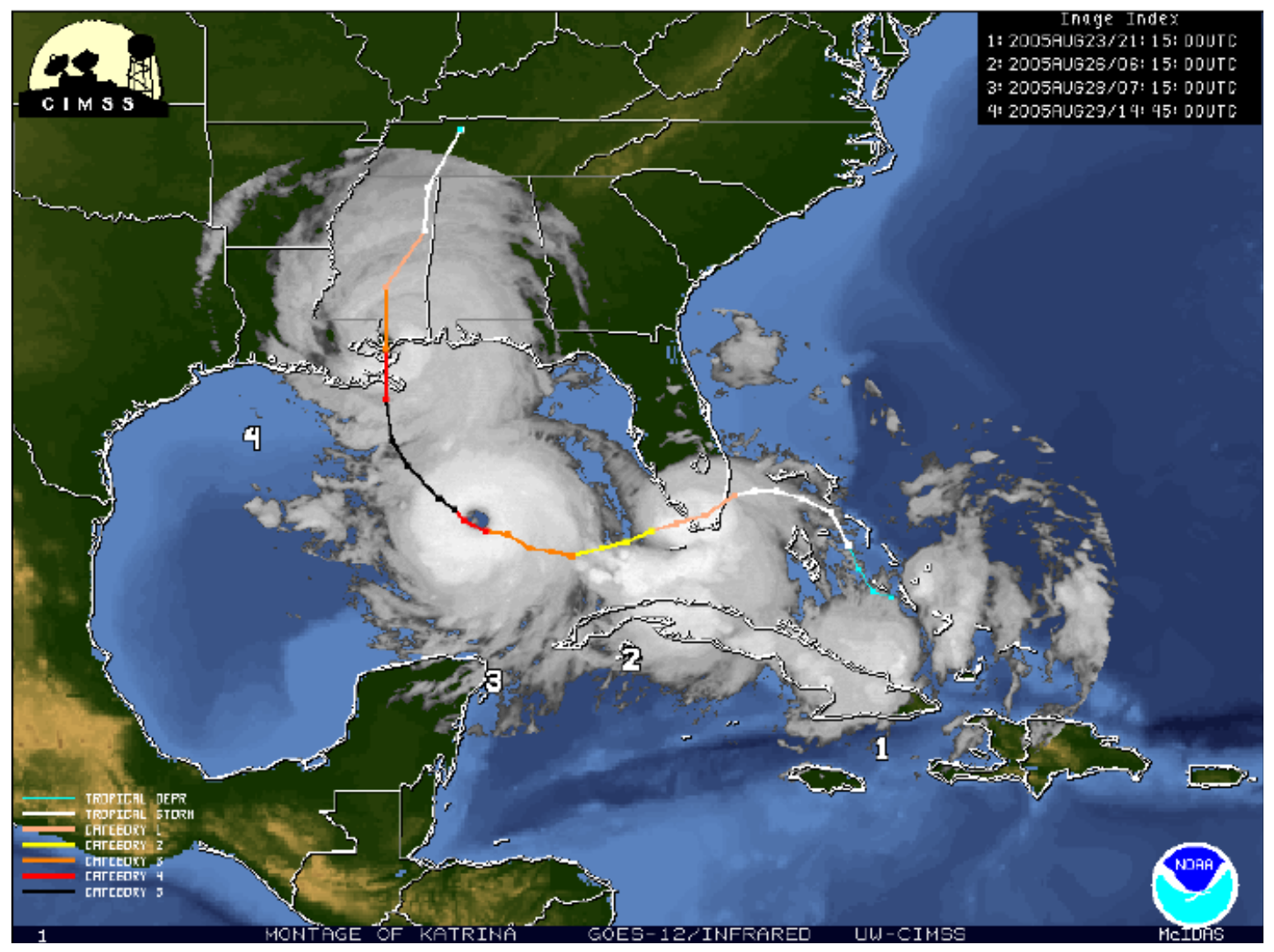

Figure 4. Track of Hurricane Katrina. Various Track Colors Indicate Category Level on the SaffirSimpson Scale.

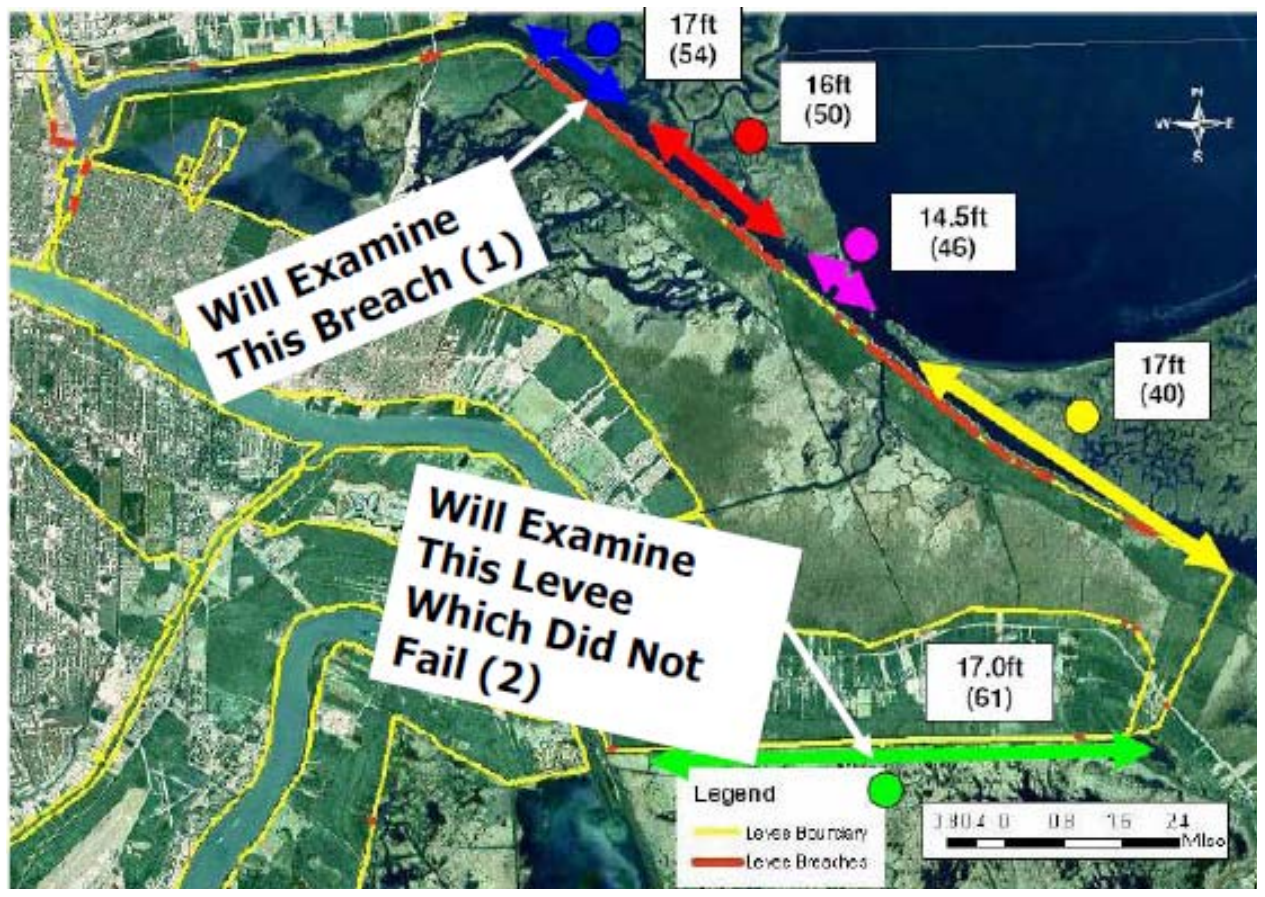

Figure 5. Locations of Two Levees Considered in This Paper 


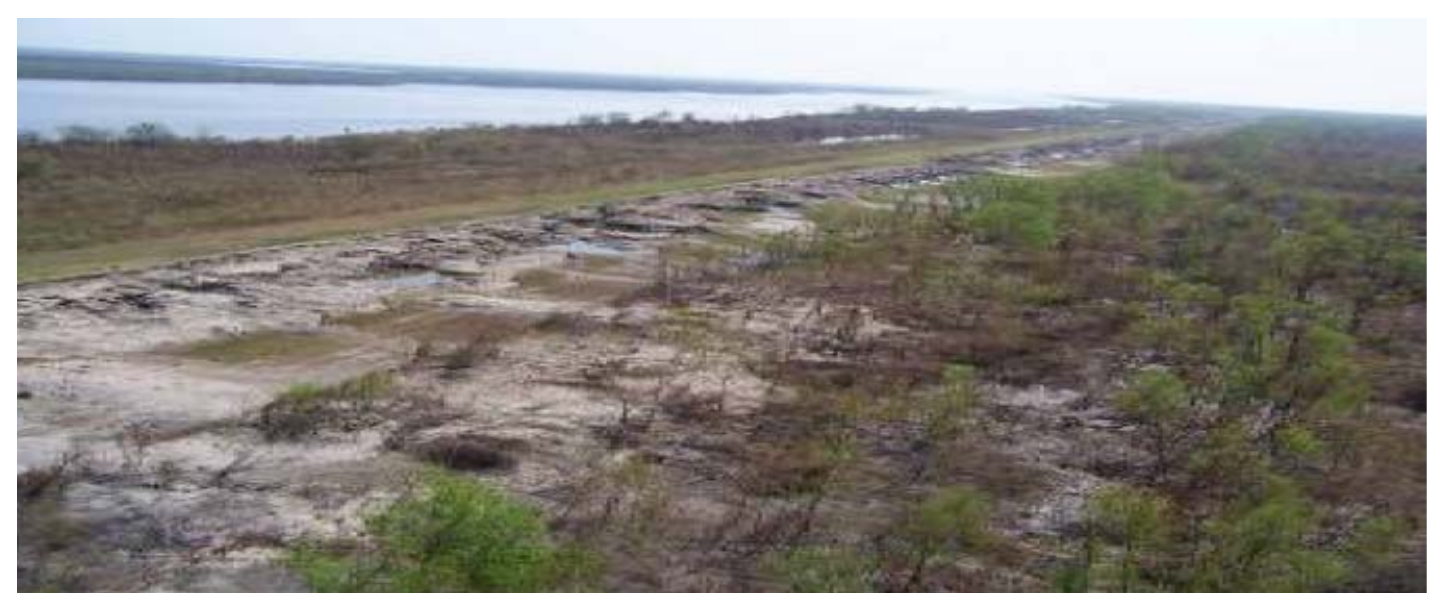

Figure 6. Extensive Breach Along the Mississippi River Gulf Outlet. (Vicinity of Location 1).

$$
\varepsilon=\frac{\overline{F_{D} u}}{S^{2}}=\frac{C_{D} \rho D h}{2 S^{2}}|u|^{3}=\frac{C_{D} \rho g^{3 / 2} D H^{3}}{12 \pi S^{2} h^{1 / 2}}
$$

which is based on linear shallow water theory and in which $\rho$ is the mass density of water, $H$ is the local wave height, $C_{D}$ is the hydrodynamic drag coefficient, $g$ is the gravitational constant, and $h$ is the local water depth. Wave energy decay is given by

$$
\frac{\partial\left(E C_{G}\right)}{\partial x}=-\varepsilon
$$

in which $E\left(=\rho g H^{2} / 8\right)$ is the wave energy density, $C_{G}(=\sqrt{g h})$ is the group velocity and $x$ is the coordinate in the wave propagation direction. Solving the above equations over a distance where the water depths change from $h_{1}$ to $h_{2}$ with a bottom slope of $m$ results in

$$
H_{2}=\frac{H_{1}\left(h_{1} / h_{2}\right)^{1 / 4}}{1-\frac{4 C_{D} D H_{1}}{3 \pi S^{2} m}\left(h_{1} / h_{2}\right)^{1 / 4}\left[1-\left(h_{2} / h_{1}\right)^{1 / 4}\right]}
$$

in which $H_{1}$ and $H_{2}$ are the significant wave heights at the start and end of the transect. Note $h_{1}>$ $h_{2}$ in this application, thus $m$ is negative. It is noted that the above equation accounts for both wave shoaling and dissipation due to the vegetation. Applying this equation for $C_{D}=1.0, D=0.05 \mathrm{~m}, S$ $=1.0 \mathrm{~m}$, and $m=0.0071$ and the wave heights at the MRGO canal where the calculated wave heights $\left(\mathrm{H}_{2}\right)$ apply results in the wave heights at the toe of the outboard levee slope shown in Figure 7. Although there is uncertainty in the values of the variables affecting wave dissipation, based on inspection of the area on several occasions, the above parameters are considered reasonable if not conservative in the sense of underestimating vegetation effects. It is seen from Figure 7 that the maximum wave height decrease is approximately $0.3 \mathrm{~m}$. 


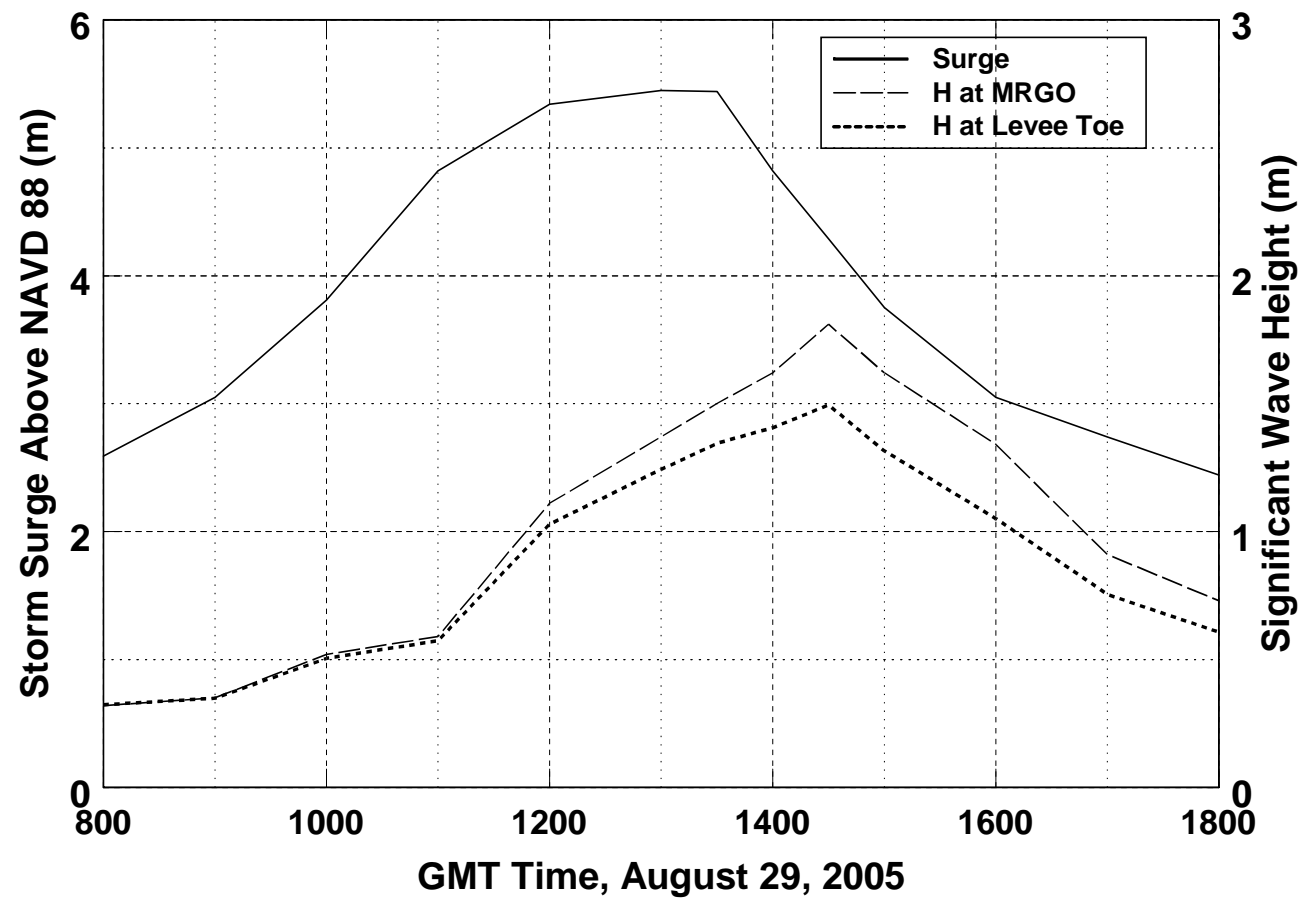

Figure 7. Wave and Surge Time Histories at Location 1. Wave Conditions at MRGO and Outboard Levee Toe Are Shown.

The wave periods and maximum wave heights considered here are presented in Table 2. Although wave periods were also calculated in the IPET investigation, they appeared too high, hence wave periods of 4 and $8 \mathrm{~s}$ are considered here.

Table 2. Maximum significant wave heights and Two wave periods considered.

\begin{tabular}{|c|c|c|}
\hline Location & Maximum Significant Wave Height $(\mathrm{m})$ & Wave Periods (s) \\
\hline \hline 1 & 1.50 & 4 and 8 \\
\hline 2 & 0.67 & 4 and 8 \\
\hline
\end{tabular}

Figure 8 presents cumulative energy erosional work units vs levee crest elevations for a wave period of 4 seconds and good, average and poor quality grass covers. The calculations consider the time histories of surge and wave characteristics at Location 1 and a range of levee heights. Levee survival (retention of function) is indicated by the levee crest elevation at which the calculated cumulative erosional work units match the allowable (Table 1). Recalling that the levee crest elevation was $5.8 \mathrm{~m}$, it is seen that the method indicates that the required levee elevations would be $6.3 \mathrm{~m}$ for good grass, $6.5 \mathrm{~m}$ for average grass and $6.8 \mathrm{~m}$ for poor grass for a wave period of $4 \mathrm{~s}$. Thus, failure of the levees due to overtopping is consistent with the results of applying this method for a wave period of 4 s. Figure 8 also indicates the benefit of grass cover quality with a good grass levee crest elevation $0.5 \mathrm{~m}$ less than for the poor quality grass. This could amount to considerable savings on long levees and although there may be some difficulty in maintaining good quality grass cover, the benefits are substantial.

Figure 9 examines the effect of wave period for the case of average grass cover at Location 1 . The required levee elevation is $8.0 \mathrm{~m}$ for a wave period of $8 \mathrm{~s}$ and $6.5 \mathrm{~m}$ for a wave period of $4 \mathrm{~s}$. These results are a direct effect of increased runup for the longer wave period. 


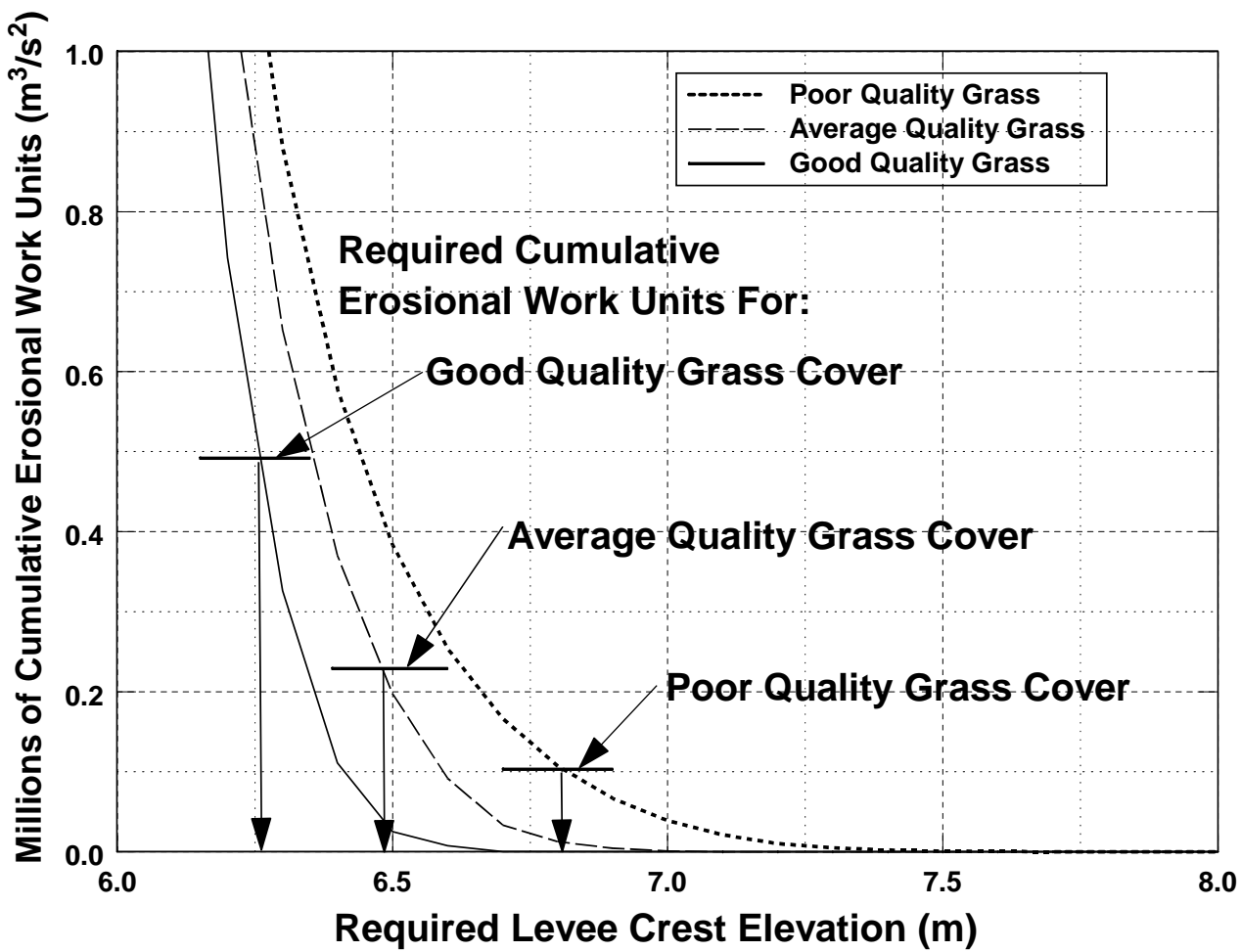

Figure 8. Required Crest Elevations for Levee to Retain Functionality at Location 1 Along St. Bernard Levee System. Wave Period = 4 s. Actual Levee Crest at Location 1 Was $5.8 \mathrm{~m}$ and Levee Failed.

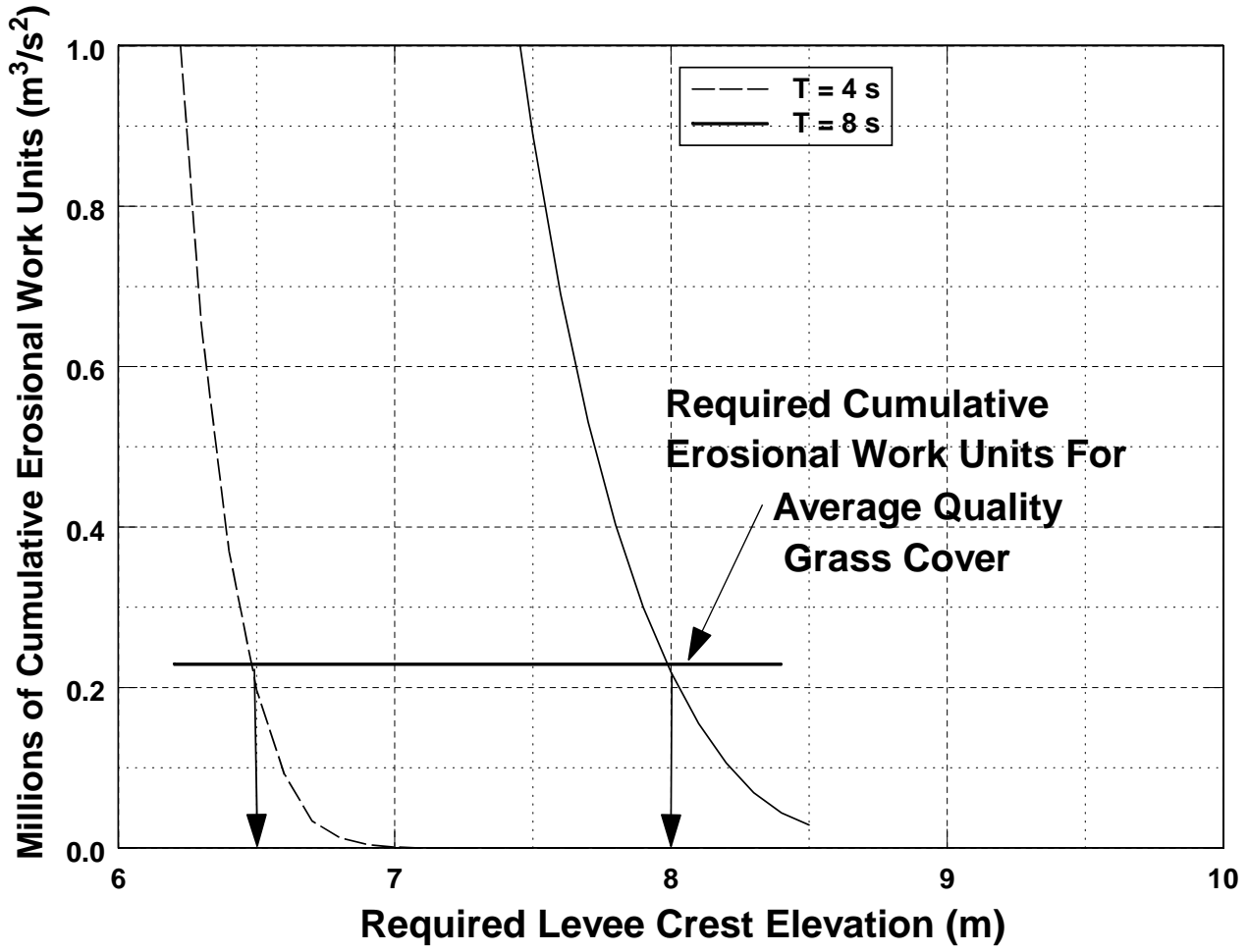

Figure 9. Effect of Wave Period on Levee Crest Elevation at Location 1. For This Location, a Wave Period of $8 \mathrm{~s}$ requires a Levee Crest Elevation $1.5 \mathrm{~m}$ Higher Than for a Wave Period of $4 \mathrm{~s}$ and Average Grass Cover Quality. 


\section{Location 2. Case of Levee Survival}

The only significant differences between Location 1 and 2 are the smaller wave heights and storm surges at Location 2 (Maximum heights: $0.67 \mathrm{~m}$ vs. $1.50 \mathrm{~m}$, Table 2 and Surges: $4.6 \mathrm{~m}$ vs. $5.4 \mathrm{~m}$ ). Figure 10 presents cumulative erosional work units vs. levee crest heights for average quality grass and a wave period of $4 \mathrm{~s}$ at Locations 1 and 2. The required levee elevations at Locations 1 and 2 are 6.5 and $5.1 \mathrm{~m}$, respectively. The required levee crest elevations for all combinations of wave period and grass cover quality are presented in Table 3. It is seen that the actual levee crest elevation of $5.8 \mathrm{~m}$ was greater than required for all grass qualities for a wave period of $4 \mathrm{~s}$ and greater than required for a period of $8 \mathrm{~s}$ and good grass quality. For a wave period of $8 \mathrm{~s}$, the actual levee crest elevation was 0.1 $\mathrm{m}$ and $0.5 \mathrm{~m}$ too low for average and poor grass qualities, respectively.

\begin{tabular}{|c|c|c|c|c|c|}
\hline \multirow{3}{*}{$\begin{array}{c}\text { Location } \\
\text { (Effect of Katrina) }\end{array}$} & \multirow{3}{*}{$\begin{array}{l}\text { Wave } \\
\text { Period } \\
\text { (s) }\end{array}$} & \multicolumn{4}{|c|}{ Levee Crest Elevation (m) } \\
\hline & & \multirow[t]{2}{*}{ Actual } & \multicolumn{3}{|c|}{ Required Elevation For Grass Quality } \\
\hline & & & Good & Average & Poor \\
\hline 1 & 4 & 5.8 & 6.3 & 6.5 & 6.8 \\
\hline 1 & 8 & 5.8 & 7.5 & 8.0 & 8.7 \\
\hline 2 & 4 & 5.8 & 5.0 & 5.1 & 5.3 \\
\hline 2 & 8 & 5.8 & 5.6 & 5.9 & 6.3 \\
\hline
\end{tabular}

\section{SENSITIVITY TESTS}

Sensitivity tests were conducted to evaluate the effects of crest elevation and wave heights on cumulative erosional work units. The results of these tests are illustrated as the variations of cumulative work units with time for various combinations of levee crest elevations and wave height characteristics.

\section{Sensitivity to Levee Crest Elevation}

Figure 11 presents the time variation of cumulative work units for levee crest elevations of $4.9 \mathrm{~m}$ and $5.0 \mathrm{~m}$ for the wave height time series at Location 2, a wave period of $4 \mathrm{~s}$ and good quality grass. The upper panel of this figure presents the wave height and storm surge time series and the lower panel presents the time variation of the two cumulative erosional work units. The erosional work units above the threshold commence at approximately 1200 GMT and continue to approximately 1400 GMT with the contributions starting somewhat earlier and ending later for the lower crest elevation. The increase in levee crest elevation by $10 \mathrm{~cm}$ results in a decrease in cumulative erosional work units by approximately two-thirds. Thus, the cumulative erosional work units are quite sensitive to levee crest elevation.

\section{Sensitivity to Wave Height}

Figure 12 presents sensitivity results due to two wave height time series, a levee crest elevation of 5.8 $\mathrm{m}$, a wave period of $4 \mathrm{~s}$ and good quality grass. The upper panel presents the two wave height time series. The smaller of the wave heights is the IPET calculated series at Location 2 and the larger wave height series is $10 \%$ greater than the smaller series. The lower panel presents the cumulative erosional work units versus time. It is seen that an increase in wave heights of $10 \%$ results in an increase in the erosional work units of approximately $60 \%$. Thus, the calculated cumulative erosional work units are quite sensitive to wave heights. 


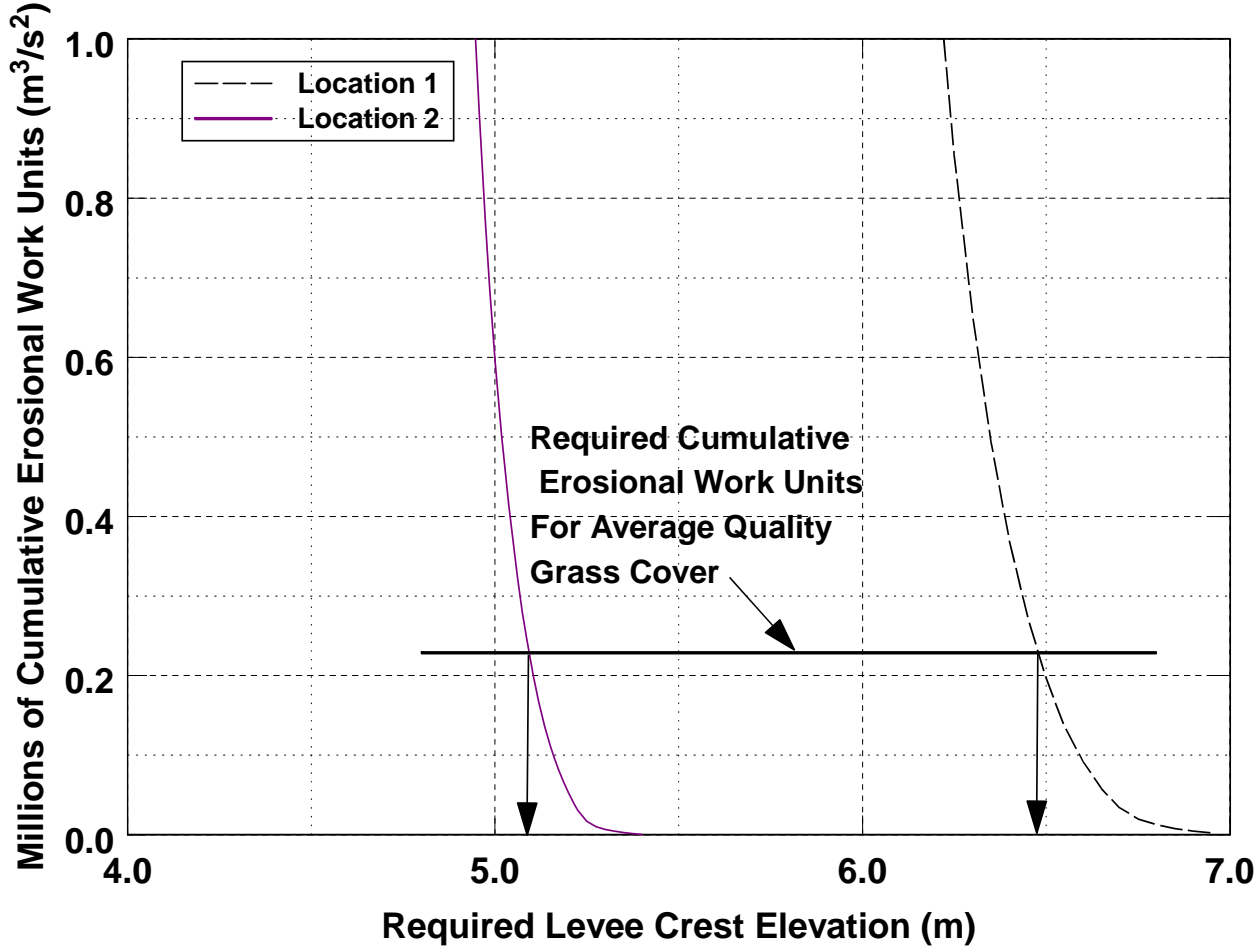

Figure 10. Required Levee Crest Elevations for Average Quality Grass and Wave Height Conditions at Locations 1 and 2 for a Wave Period of $4 \mathrm{~s}$.

\section{COMPARISON WITH EARLIER GUIDANCE}

It is of interest to compare the results of the method presented herein with guidance provided in the TAW and EuroTop Manuals. As noted previously, the guidance in those two manuals does not account for overtopping duration although the need is recognized. Rather, only magnitudes of overtopping for the following three grass qualities are considered: Good (10 liters/s-m), Average (1 liter/s-m) and Poor (0.1 liter/s-m).The TAW equations for the allowable average overtopping rates are:

$$
q_{\text {all }}=\left\{\begin{array}{l}
0.067 \sqrt{\frac{g H_{m o}^{3} \tan \alpha}{H_{m o} / L_{o}}} e^{-\frac{4.3 Z_{c} \sqrt{H_{m o} / L_{o}}}{H_{m o} \tan \alpha}}, \quad \xi_{o}<1.8 \\
0.2 \sqrt{g H_{m o}^{3}} e^{-\frac{2.3 Z_{c}}{H_{m o}}}, \quad \xi_{o}>1.8
\end{array}\right.
$$

In which $Z_{c}$ is the freeboard (levee crest height relative to the peak storm surge), $\xi_{o}\left(\equiv \frac{\tan \alpha}{\sqrt{H_{m o} / L_{o}}}\right)$ is the Iribarren Number, $H_{m o}$ is the significant wave height at the outboard toe of the levee, and $L_{o}\left(\equiv \frac{g T^{2}}{2 \pi}\right)$ is the deep water wave length and $\tan \alpha(=1 / 3.5)$ is the slope of the levee. The above equations can be inverted to calculate $Z_{c}$ 
$Z_{c}=\left\{\begin{array}{l}-\frac{H_{m o} \tan \alpha}{4.3 \sqrt{H_{m o} / L_{o}}} \ln \left(\frac{q_{\text {all }}}{0.067 \sqrt{\frac{g H_{m o}^{3} \tan \alpha}{H_{m o} / L_{o}}}}\right), \quad \xi_{o}<1.8 \\ -0.2 \frac{H_{m o}}{2.3} \ln \left(\frac{q_{\text {all }}}{0.2 \sqrt{g H_{m o}^{3}}}\right), \quad \xi_{o}>1.8\end{array}\right.$
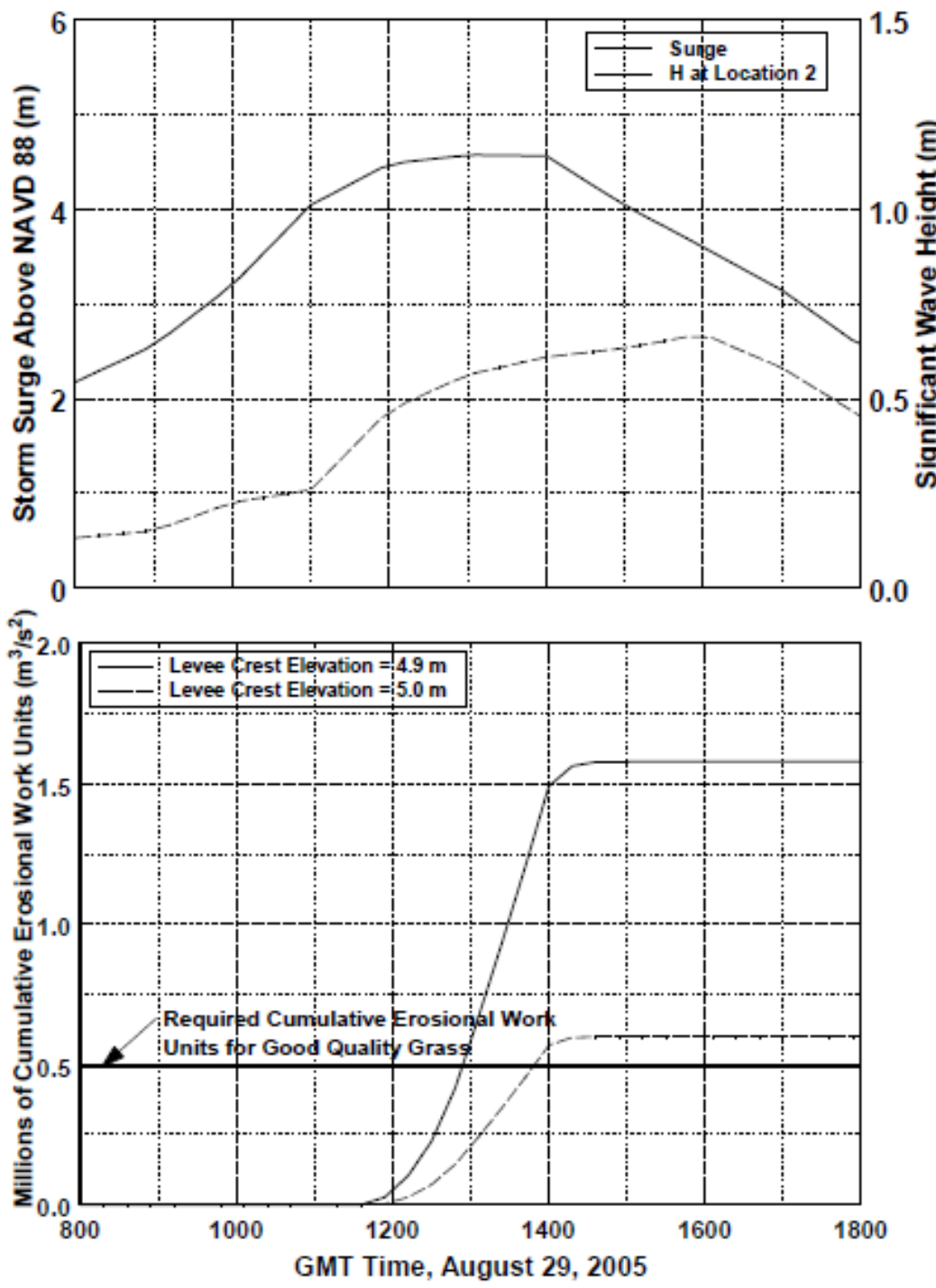

Figure 11. Variation of Cumulative Erosion Work Units With Time for Two Levee Crest Elevations for Conditions at Location 2 (Lower Panel). Wave Period = 4s. Wave Height and Surge Shown in Upper Panel. Good Quality Grass. Illustrates Sensitivity to Levee Crest Elevation. 

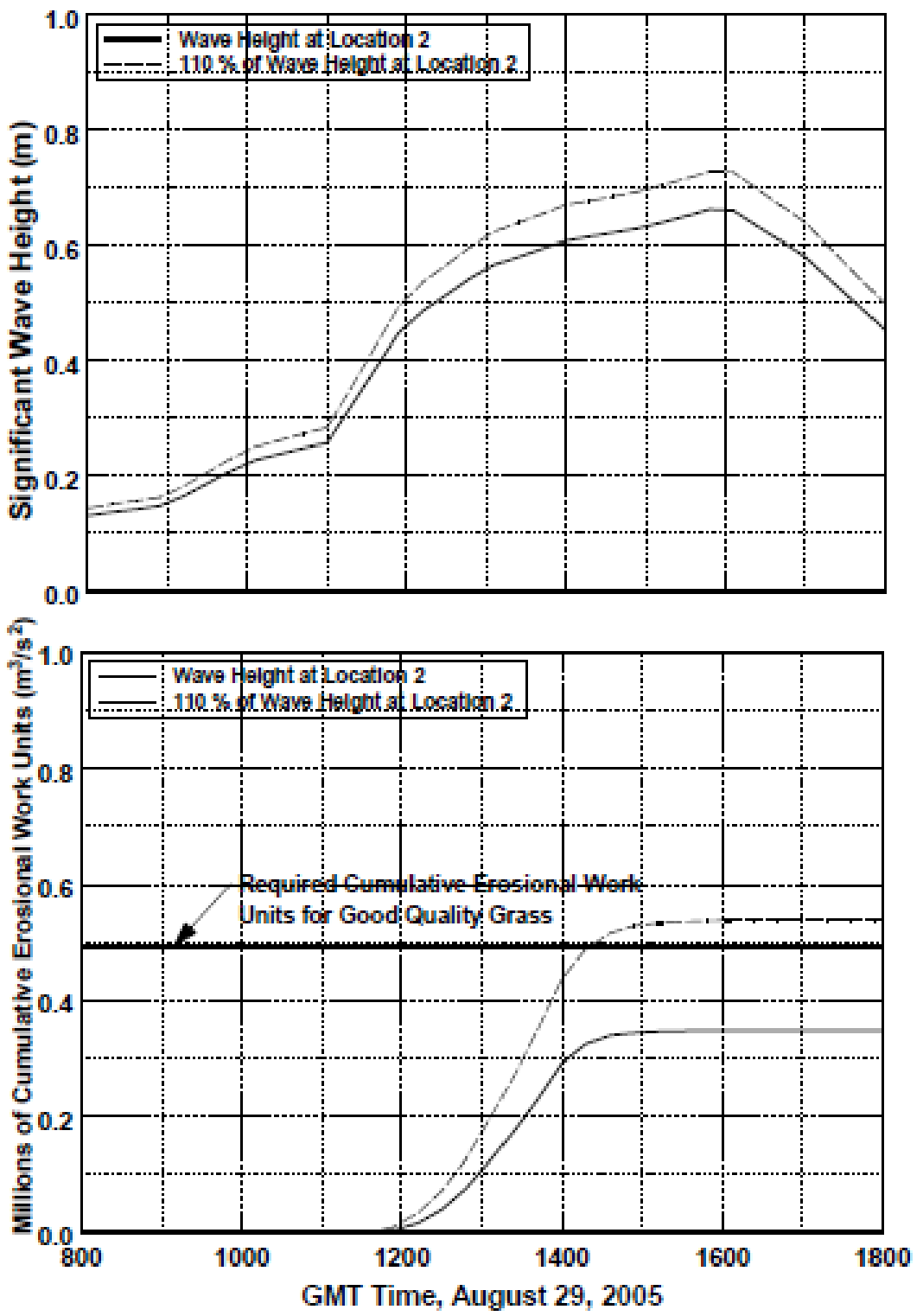

Figure 12. Variation of Cumulative Erosion Work Units With Time for Two Wave Height Series With the Second Series of Wave Heights 10\% Higher Than Those at Location 2. Crest Elevation $=5.8 \mathrm{~m}$, Wave Period $=4 \mathrm{~s}$. Time Histories of Wave Heights Shown in Upper Panel. Good Quality Grass. Illustrates Sensitivity to Wave Heights.

Table 4 compares, for the twelve cases previously considered in Table 3, the required levee crest elevations to satisfy requirements with the previous guidance and by the method herein. It is seen that the TAW methodology predicts levee crest elevations that are generally considerably higher than those associated with the method described herein with the TAW elevations higher than those developed here by a range from $0.5 \mathrm{~m}$ to $3.1 \mathrm{~m}$. Because the methods herein appear to agree reasonably well with the failure at Location 1 and the non-failure at Location 2 for good quality grass, it appears that the TAW methodology is conservative. This same general conclusion has been reached independently by tests with the Wave Overtopping Simulator discussed earlier. 


\begin{tabular}{|c|c|c|c|c|}
\hline \multirow{2}{*}{$\begin{array}{l}\text { Location } \\
\text { (Effect of } \\
\text { Katrina) } \\
\end{array}$} & \multirow{2}{*}{$\begin{array}{c}\text { Wave Period } \\
\text { (s) }\end{array}$} & \multicolumn{3}{|c|}{ Required Crest Elevation (m) For Grass Quality } \\
\hline & & Good & Average & Poor \\
\hline 1 & 4 & $6.8(6.3)$ & $7.6(6.5)$ & $8.4(6.8)$ \\
\hline 1 & 8 & $8.7(7.5)$ & $10.2(8.0)$ & $11.8(8.7)$ \\
\hline 2 & 4 & $5.3(5.0)$ & $5.8(5.1)$ & $6.3(5.3)$ \\
\hline 2 & 8 & $6.3(5.6)$ & $7.3(5.9)$ & $8.3(6.3)$ \\
\hline
\end{tabular}

\section{SUMMARY}

This paper has presented a blinded-folded comparison of required levee crest elevations for retention of levee function at two locations in the St. Bernard levee system (New Orleans area) for Hurricane Katrina (2005) conditions. The levees were located approximately $15.5 \mathrm{~km}$ apart and one levee failed and the other survived. The storm surge histories at the two sites were calculated with ADCIRC and the wave heights were calculated with STWAVE. The surges and wave heights at Location 1 were higher than at Location 2. Because of the uncertainty in wave periods, wave periods of 4 and $8 \mathrm{~s}$ are considered.

Findings are absolutely consistent with levee failure at Location 1 for all grass cover qualities and the levee survival at Location 2 for good quality grass cover. The levee at Location 1 failed at a crest elevation of $5.8 \mathrm{~m}$ and the method indicated that for the calculated wave and surge hurricane conditions, levee crest elevations of $8.7 \mathrm{~m}$ and $6.8 \mathrm{~m}$ would be required for wave periods of $8 \mathrm{~s}$ and $4 \mathrm{~s}$, respectively for good quality grass. For poor quality grass cover, required levee crest elevations of 11.8 and $8.4 \mathrm{~m}$ are indicated. Results presented illustrate the effects of levee crest elevation, grass cover and wave period.

At Location 2 where the levee survived with crest elevation of $5.8 \mathrm{~m}$, the results indicated required crest elevations varied from $5.0 \mathrm{~m}$ to $5.3 \mathrm{~m}$ for the three grass cover qualities and a wave period of $4 \mathrm{~s}$. For a wave period of $8 \mathrm{~s}$, the required levee crest elevations varied from $5.6 \mathrm{~m}$ to $6.3 \mathrm{~m}$ for the three grass cover qualities.

Sensitivity tests were conducted to demonstrate the effects of storm surge and wave height. Further effort is warranted to investigate the interrelationships between wave heights and periods, storm surge elevation, grass cover quality, and required crest elevation for non-failure.

The results of the methodology presented herein are compared with the TAW methodology which does not consider the effects of storm duration. It appears that the TAW methodology may be conservative for the ranges of hydrodynamic and levee conditions considered here.

The two comparisons presented here are limited due to uncertainties in levee grass quality and some uncertainties in storm surge and wave characteristics. Additional full scale comparisons are required to further evaluate the method. These comparisons could include additional locations affected by Hurricane Katrina and results obtained from the full scale Wave Overtopping Simulator.

Although not illustrated here, the method has the advantage of allowing optimization of levee design in which, for given design wave and surge conditions, elevation and slope parameters can be evaluated to minimize the levee volume and the probability of failure. Additionally, the method is amenable to Monte Carlo simulation in which uncertainties in grass cover quality and other levee and forcing conditions are represented by probability distributions such that the probability characteristics of failure are quantified. 


\section{REFERENCES}

Akkerman, D. Barnadini, J. Van der Meer, A. Van Houen (2007) "Field Tests on Sea Defences Subject to Wave Overtopping”, Proceedings, ASCE Coastal Structures Conference, Venice, Italy.

Dean, R. G. (1978) “Effects of Vegetation on Shoreline Erosional Processes,” Proceedings, National Symposium on Wetlands, November, pp. 415-426.

Dean, R. G., J. D. Rosati, T. L. Walton and B. E. Edge (2010) "Erosional Equivalencies of Levees: Steady and Intermittent Wave Overtopping”, Ocean Engineering, Vol. 37, pp. 104-113.

Hewlett, H. W. M., L. A. Boorman and M. E. Bramley (1987) "Design of Reinforced Grass Waterways", CIRIA Report 116, Construction and Industry Research and Information Association, London.

Hoffmans, G. G. J. Akkerman, H. J. Verheij, A. Van Hoven and J. W. Van der Meer (2008) The Erodibility of Grassed Inner Dike Slopes Against Wave Overtopping”, Proceedings of the 31st International Conference of Coastal Engineering, Hamburg, Germany, pp. 2,944 - 2,956.

Kobayashi, N., A. W. Raichle and T. Asano (1993) “Wave Attenuation by Vegetation”, J. Waterway, Port and Coastal Engineering, Vol.199, No. 1, pp. 30 - 48.

Lima, S. F., C. F. Neves, and N. M. L. Rosauro (2006) "Damping of Gravity Waves by Fields of Flexible Vegetation", Proceedings of the $30^{\text {th }}$ International Conference of Coastal Engineering, San Diego, CA, pp. 491 - 503.

Schüttrumpf, H. (2003) "Wave Overtopping Flow on Seadikes - Experimental and Theoretical Investigations”, PIANC Bulletin 149.

U. S. Army Corps of Engineers (2008a) "Coastal Engineering Manual”, Available at: http://chl.erdc.usace.army.mil/Media/2/0/7/CEM_Part-VI_Chap-5-pt1.pdf

U. S. Army Corps of Engineers (2008b) "Performance Evaluation of the New Orleans and Southeast Louisiana Hurricane Protection System: Final Report of the Interagency Performance Evaluation Task Force”, Available at: https://ipet.wes.army.mil/

Van der Meer, J. W. (2002) “Technical Report: Wave Run-up and Wave Overtopping at Dikes”, Technical Advisory Committee on Flood Defence, (herein referred to as the "TAW Manual”), Delft.

Van der Meer, J. W., D. Bernardini, W. Snijders, and E. Regeling (2006) “The Wave Overtopping Simulator”, Proceedings of the $30^{\text {th }}$ International Conference of Coastal Engineering, San Diego, CA, pp. $4654-4664$.

Van der Meer, J. W. (2008) "Erosion Strength of Inner Slopes of Dikes Against Overtopping: Preliminary Conclusions After Two Years of Testing With the Wave Overtopping Simulator, ComCoast, Rijkswaterstaat-Dienst Weg- en Waterbouwkunde, Rijkswaterstaat-Waterdienst, Projectbureau Zeeweringen.

Whitehead, E., M. Schiele and W. Bull (1976) “A Guide to the Use of Grass in Hydraulic Engineering Practice”, CIRIA Report 71, Construction and Industry Research and Information Association, London.

Young, M. J. (2005) "Wave Overtopping and Grass Cover Layer Failure on the Inner Slope of Dikes”, MSc Thesis WSE-CEPD-05.03, UNESCO-IHE.

Storesund, R., R. G. Bea and Y. Huang (2010) "Simulated Wave-Induced Erosion of the Mississippi River-Gulf Outlet Levees During Hurricane Katrina”, Journal WPCOE, ASCE, pp. 177-189.

Van der Meer, J. W. (2002) “Technical Report: Wave Runup and Wave Overtopping at Dikes”, Technical Advisory Committee on Wave Overtopping at Dikes. Technical Committee on Flood Defence. (Herein referred to as the “TAW Manual”). 